\title{
IRRIGATION GURMA WATERMELON IN OLD VALLEY BY GATED PIPES AND SIPHONS.
}

\author{
EL- Sharkawey. A.F. ${ }^{1}$ And Bondok .M.Y. ${ }^{2}$
}

\begin{abstract}
This investigation was carried out in Gemmeiza Agric . Res. St. during season 2010/2011 to study the effect of irrigation systems, i.e. traditional, siphon and gated pipes, planting methods (planting one ridge with width $1.25 \mathrm{~m}$ and planting two ridges with width $2.5 \mathrm{~m}$ ) and the influence of different irrigation regimes (irrigation at 40\%, 60\% and $80 \%$ ) of the available soil moisture depletion, on yield and components and water use efficiency for watermelon .Data indicated that the better vegetative growth plant parameters (fresh weight, stem length and number of branches /plant the ratio was 9.36, 7.25 and $22.91 \%$ resp.) ,fruit characters (fruit weight, length and diameter the ratio was 6.89, 11.09 and $21.7 \%$ resp. ), fruits shape homogenous by $9 \%$ (ratio length/ diameter ), yield by $7.25 \%$ and water use efficiency by $32.36 \%$ resulted when using gated pipes compared with the traditional irrigation system . Planting methods for tested irrigation system gurma watermelon under study by increased width of $2.5 \mathrm{~m}$ with planting two ridges increase vegetative growth parameters (fresh weight, stem length and number of branches /plant by $2.65,3.77$ and $6.93 \%$ resp.), fruit characters (fruit weight, length and diameter), fruit shape homogenuity (ratio length/ diameter by 2.37, $6.62,13.92$ and $7.34 \%$ resp.) ,yield and water use efficiency (W.U.E.) by 4.27 and $15.41 \%$ compared to planting one ridge with width $1.25 \mathrm{~m}$. Subjecting Gurma watermelon plants to droughtstress to 60and $80 \%$ compared to irrigated at $40 \%$ soil depletion reduced in vegetative growth parameters (fresh weight, stem length and number of branches /plant by 3.87, $7.03,4.76,9.54$ and $10.81,14.62 \%$ resp. ) ,fruit characters ( fruit weight, length and diameter by $2.43,5.89,4.18$ , 8.19 and $5.20,10.93 \%$ resp. ), and yield by 5.52 and $7.05 \%$.
\end{abstract}

1. senior richer. Agric. Eng. Res. Instit. Dokki, Giza.

2. head of rehears emit. Agric. Eng. Res. Instit. Dokki, Giza. 
To save irrigation water, increase yield and W.U.E. ,it is recommended to irrigate by gated pipes, planting two ridges with width of $2.5 \mathrm{~m}$ and irrigating after depletion of $40 \%$ of available soil moisture under Gemmeiza conditions .

\section{INTRODUCTION}

7 he economic importance of Gurma watermelon has recently increased because its production exceeds the domestic consumption, and hence the country becomes able to export large quantities of Gurma watermelon to Arab countries . Very little researches have been conducted to evaluate the effect of cultural practices on the growth and seed yield of Gurma watermelon .

Distribution uniformity and Water Use Efficiency(WUE), fertilization and use of chemicals are major problems under different irrigation methods in old lands in all cases, quantity and quality of yield reduction, introduction of the proper design of modified irrigation systems will be the main tools to obtain uniform distribution of the applied water, fertilizers and chemicals in order to maximize crop yield and overcome environmental problems .

Abo soliman et al . (2005) indicated that the irrigation by gated pipe a chieved the highest values of yield and saved amount of irrigation water applied by 11.9 $\%$.

Abdel -Aziz. (2003) said that irrigation water requirements for citrus were reduced by $44.4 \%, 37.5 \%$ and $23.1 \%$ when using drip ,bubbler and gated pipes irrigation systems respectively compared to the traditional surface irrigation .

.Attia et al (1999) stated that, the irrigation of soybean with $90 \mathrm{~cm}$ between rows reduced amount of applied irrigation water by 19.7 and $18.8 \%$ in two growing seasons respectively, and the same treatment saved about 20.6, 41.9 and $38.5 \%$ of the time needed for sowing, thinning and irrigation respectively when it was compared with the treatment $60 \mathrm{~cm}$ between rows

Humpherys .(1986) found that gated pipe in one of the techniques where water flow could be controlled for better uniformity and efficiency. The gated pipe lines installed in a series of level sections at both the upper end and middle the field. 
Osman et al.( 2005) indicated that irrigation requirements using gated pipe system is better than traditional irrigation method .Gated pipes irrigation system saves $19.81 \%$ compared to traditional irrigation method .

Omara .(1997) found that the irrigation application efficiency and irrigation distribution efficiency increased to $72.5 \%$ and $92 \%$ respectively by using gated pipes .

Yousef and Eid .(1994) found that irrigation at a depletion of $30 \%$ of available soil moisture gave the highest grain and straw yields and WUE values for Sakha 69 wheat cultivar .lHefnawy and Wahba . 2003 ) found that water stress at late growth stages reduced grain yield by 6.96 and $15.04 \%$ and biological yield by 8.5 and $8.5 \%$ compared with non stressed plants Mahgoub and Sayed . (2001) reported that increasing irrigation water from 750 to $2400 \mathrm{~m}$ resulted in corresponding significant increases in wheat grain yield and its components . Hefni et al (1994) found that the highest W U E $\left(1.4 \mathrm{~kg} / \mathrm{m}^{3}\right.$ was obtained from treatment irrigated at $40 \%$ soil moisture depletion. Meanwhile the lowest value W U E $\left(1.35 \mathrm{~kg} / \mathrm{m}^{3}\right)$ was obtained from treatment irrigated at $80 \%$ soil moisture depletion. Shalaby et al.(1992) found that irrigation after high soil moister depletion significantly decreased plant height, number of tillers, number of spikes $/ \mathrm{m}^{2}$, number of grains / spike ,1000 -grain weight and grain and straw yield .

The objective of this investigation was to study the effect of irrigation systems , planting distribution ; effect of different irrigation regimes and their interaction on growth, yield and its components of Gurma watermelon .

\section{MATERIALS AND METHODS}

The study was carried out during the period from June 2011 to September 2011 at Gemmeiza Res. Sta. farm to study Gurma watermelon growth and yield as influenced by some irrigation systems in old valley. Seeds were sown on 10 June 2011 and harvested on October 20. The experimental design was random complete blocks design with three replicates. The width of furrow was ( 1.25 and $2.5 \mathrm{~m}$ ) with planting (one and two ridges), and one plant per hill with $50 \mathrm{~cm}$

The plot area was $250 \mathrm{~m}$ (4 rows , $1.25 \mathrm{~m}$ width , $50 \mathrm{~m}$ length) and (2 rows, $2.5 \mathrm{~m}$ width $.50 \mathrm{~m}$ length). All recommended agricultural practices (i.e. fertilization, weed control ...etc) for Gurma production in Gemmeiza area were done. 
The culture practices were according to the general program of gurma water melon cultivation. Plants were irrigated by gated pipe ; siphon and traditional surface irrigation. Water was applied to the plants when water depletion was $40-80 \%$ from available water capacity of soil in gated pipe ,siphon and traditional surface irrigation.

Main - plot (irrigation systems )

$\mathbf{1}$ - gated pipes irrigation (GI)

2- siphon irrigation (SI)

3- - traditional surface irrigation. (TI)

Sub main - plot (planting methods )

1- One plant /hill on one side of ridge (width of furrow $1.25 \mathrm{~m}$ )

2- One plant / hill on both two sides of the ridge (width of furrow $2.5 \mathrm{~m}$ )

Sub sub main plot (ratio of soil moisture depletion)

1- irrigated at $40 \%$ soil moisture depletion . $\mathrm{I}_{1}$

2- irrigated at $60 \%$ soil moisture depletion $\mathrm{I}_{2}$

3- irrigated at $80 \%$ soil moisture depletion $\mathrm{I}_{3}$

The soil texture of the experimental site is classified as clay soil experimental in soil lap in Gemmeiza Res. Sta.

Irrigation systems:

1 -Irrigation water calculations:

a . Traditional irrigation system.

Irrigation water was delivered to the plots through a circular orifice and water quantity was measured using the formula of immersed orifice according James(1988) 


$$
\mathrm{Q}=0.61 \mathrm{~K} \mathrm{AH}^{0.5} \quad \text { James (1988)- }
$$

Where:

$\mathrm{Q}=$ Orifice discharge $\mathrm{L} / \mathrm{sec}$.

$\mathrm{A}=$ the area of orifice opening $\left(\mathrm{cm}^{2}\right)$

$\mathrm{H}=$ Effective water head over the orifice center ( $\mathrm{m}$.)

$\mathrm{K}=$ Unit constant $\left(\mathrm{K}=0.443\right.$ for $\mathrm{Q}$ in $\mathrm{L} / \mathrm{sec}$, $\mathrm{A}$ in $\mathrm{cm}^{2}$, and $\mathrm{H}$ in $\mathrm{m}$ )

\section{B. Siphon}

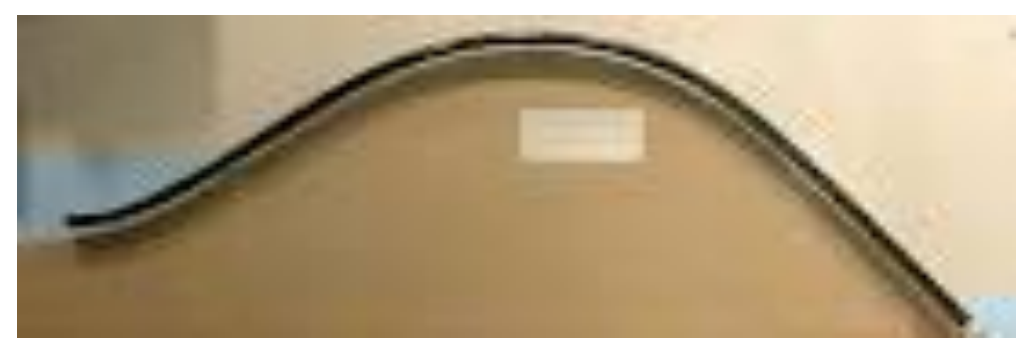

(Siphon)

$$
Q=\frac{\pi D^{2}}{4}\left(\frac{2 g \Delta H}{1.9+f \frac{L}{D}}\right)^{0.5}
$$

Israelsen and Hansen (1962)

(2)

where
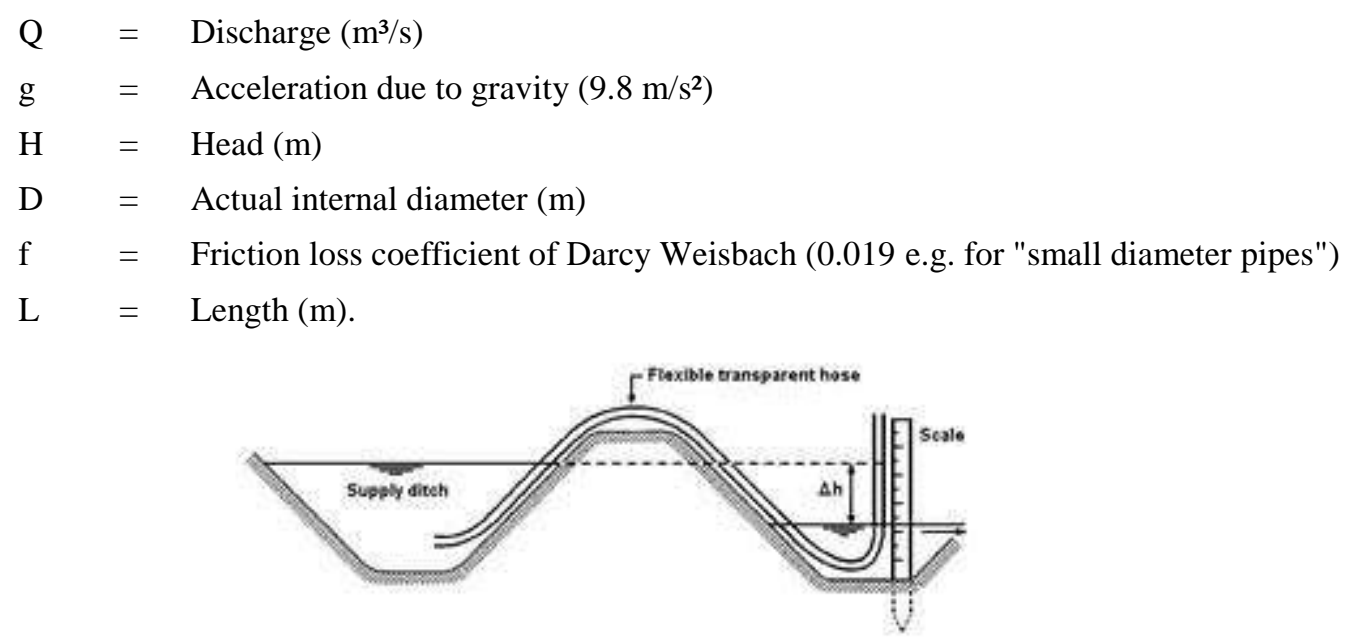


\section{Gated pipes.}

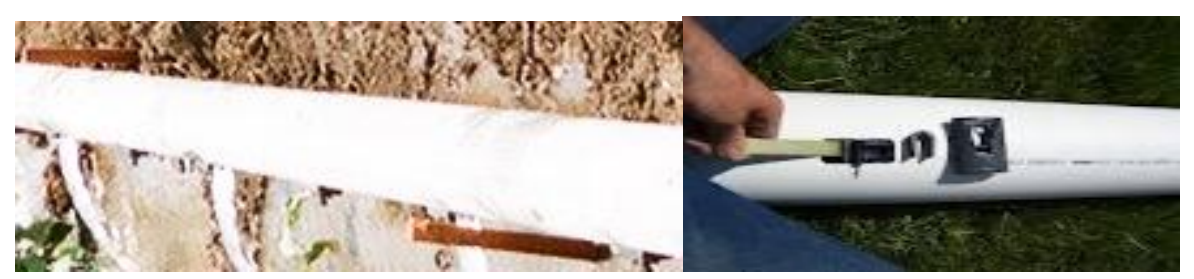

Gated pipes irrigation system.

$$
\left(A=(p i) D^{2} / 4\right.
$$

where:

$\mathrm{A}=$ Tube inside cross sectional area $\mathrm{cm}^{2}$

$\mathrm{D}=$ inside diameter pipe $\mathrm{m}$

$\mathrm{Q}=$ Maximum flow rate at the pipe

$$
\mathbf{Q}=\mathbf{A} \times \mathbf{V m a x}
$$

Where

$\mathrm{Q}=$ Maximum flow rate at the pipe $\mathrm{m}^{3} / \mathrm{sec}$

$\mathrm{V}=\max$. water velocity to cause no soil erosion. $\mathrm{m} / \mathrm{sec}^{2}$

*Furrow irrigation system.

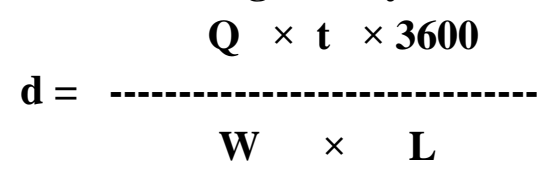

\section{Where :}

$\mathrm{d}=$ average irrigation water depth $\mathrm{cm}$

$\mathrm{Q}=$ discharge for every lateral $\mathrm{L} / / \mathrm{sec}$

$\mathrm{t}=$ time for irrigation hour

$\mathrm{W}=$ spacing between laterals $\mathrm{m}$.

$\mathrm{L}=$ length of line $\mathrm{m}$.

\section{2- Moisture content:}

Water holding capacity (W.H.C) $\mathrm{mm}$ :

W.H.C $=$ FC $\%-$ PWP $\% \times$ bulk density $\times$ root zone, $\mathrm{m} \times 10$ where: 
FC is field capacity.

PWP is permanent wilting point.

Maximum net water requirement (Max - n.w .r ) mm.

Max. n.w. $\mathrm{r}=$ MAD $\times$ W.H.C $\div 100$.

M A D =Moisture available deficit $\mathrm{mm} / \mathrm{m}$.

Maximum gross water requirement ( max- g.w.r ) mm

Max-g.w.r. $=$ max-n.w.r. $\times 100 \div \mathrm{AE}$

Field WUE :

FWUE $=\{$ Average yield, $\mathrm{kg} / \mathrm{Fed}\}$

$$
\left\{\text { Applied water, } \mathrm{m}^{3} / \text { Fed }\right\}=
$$

F W U E for crop is the weight of marketable crops produced per volume unit of applied water expressed as cubic meters of water (Michael, 1978).

\section{Yield:}

At harvest yield of selected crops, determined from the field and computed (T/F).Yield and its components, number of fruit / plant, weight of 100 seed, weight seeds in fruit and seeds yield ( $\mathrm{kg} / \mathrm{fed}$.)

Fruit traits: at harvesting time, a random sample of 10 fruits was taken from each experimental unit to estimate fruit weight, fruit length and diameter $(\mathrm{cm})$.

\section{RESULTS AND DISCUSSION}

\section{1-Irrigation water.}

Irrigation water for Gurma watermelon and saving under some different irrigation systems ( gated pipe, siphon and traditional irrigation systems) , depletion ratio of the available soil moisture( irrigated at depletions 40 $\%, 60 \%$ and $80 \%$ of available water), and planting methods( width $1.25 \mathrm{~m}$ with planting on one ridge and width $2.5 \mathrm{~m}$ with planting two ridges )

\section{1-1 Effect of irrigation systems.}

Data in Table ( 1 ) indicated that irrigation water applied for watermelon was reduced by 11.83 and $18.30 \%$ by using siphon and 
gated pipes irrigation comparing with traditional irrigation .water use saving water losses due to deep percolation.

Table ( 1) :Effect of irrigation systems, depletion of available water and planting methods on amount irrigation water.

\begin{tabular}{|l|c|c|c|c|}
\hline $\begin{array}{l}\text { Irrigation } \\
\text { systems }\end{array}$ & $\begin{array}{c}\text { Depletions } \\
\text { of available } \\
\text { water }\end{array}$ & $\begin{array}{c}\text { Amount of } \\
\text { irrigation } \\
\text { water cm.. }\end{array}$ & $\begin{array}{c}\text { Planting } \\
\text { methods. }\end{array}$ & $\begin{array}{c}\text { Amount of } \\
\text { irrigation } \\
\text { water cm.. }\end{array}$ \\
\hline Traditional & $\mathbf{I}_{\mathbf{1}}$ & 56.76 & $\mathbf{R}$ & 56.22 \\
\hline & $\mathbf{I}_{\mathbf{2}}$ & 51.00 & $\mathbf{2 R}$ & 48.61 \\
\hline & $\mathbf{I}_{\mathbf{3}}$ & 48.15 & & \\
\hline Average & & 51.97 & & 51.97 \\
\hline Siphon & $\mathbf{I}_{\mathbf{1}}$ & 48.46 & $\mathbf{R}$ & 48.66 \\
\hline & $\mathbf{I}_{\mathbf{2}}$ & 46.00 & $\mathbf{2 R}$ & 43.66 \\
\hline & $\mathbf{I}_{\mathbf{3}}$ & 43.00 & & \\
\hline Average & & 45.82 & & 45.82 \\
\hline Gated pipe & $\mathbf{I}_{\mathbf{1}}$ & 45.38 & $\mathbf{R}$ & 43.37 \\
\hline & $\mathbf{I}_{\mathbf{2}}$ & 42.00 & $\mathbf{2 R}$ & 41.46 \\
\hline & $\mathbf{I}_{\mathbf{3}}$ & 40.00 & & \\
\hline Average & & 42.46 & & 42.46 \\
\hline
\end{tabular}

\section{1-2 Depletion of available water.}

Data in fig. (1) show that under all irrigation systems ( traditional, siphon and gated pipes ) increasing depletion of available water from 40 , 60 and $80 \%$,decreases amount of irrigating water this due to decrease number of irrigations . Amount of irrigation water under depletions $40 \%$ $56.76,48.46$ and $45.38 \mathrm{~cm}$. respectively .Was determine under using traditional ,siphon and gated pipes. Depletion of available was used water at $60 \%$ amount of water 52.35, 46.05 and $42.97 \mathrm{~cm}$ by using irrigating systems. The lowest values of irrigation water under depletion of available water $80 \%$ were $49.15,44.85$ and $40.77 \mathrm{~cm}$. by using the irrigation systems. 


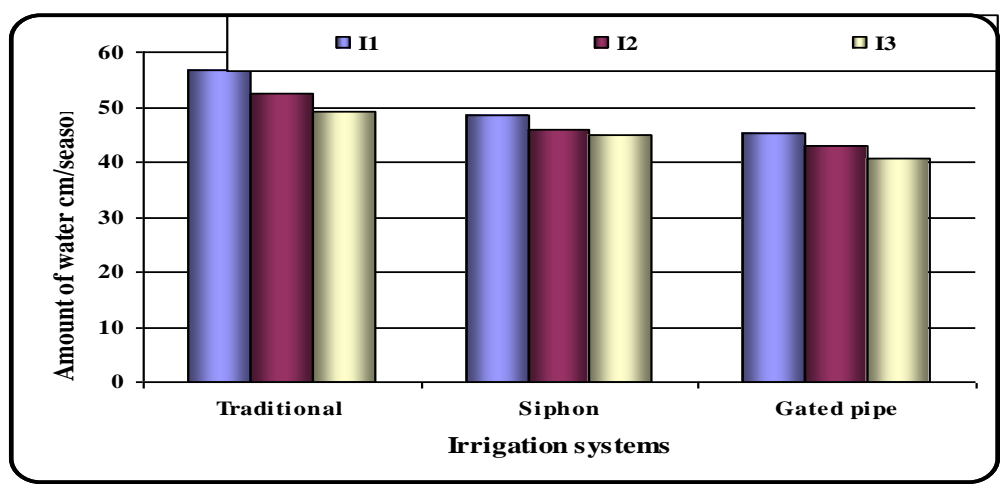

Fig. (1) Effect of available water depletion under irrigation systems on amount of water .

Data in table ( 1 ) indicated that irrigation water decreased by 7.71 and $12.35 \%$ for $\mathrm{I}_{2}$ (irrigation at depletion of available water $60 \%$ )and $\mathrm{I}_{3}($ irrigation at depletion of available water $80 \%$ ) compared to $\mathrm{I}_{1}$ (irrigation at depletion of available water $40 \%$ ). These results due to decreased irrigation number by increased depletion of available water .

\section{1-3 Effect planting methods}

Effect of planting methods on amount of irrigation systems under irrigation systems is shown in Fig (2).We found decrease amount of water irrigation under all irrigation systems by planting two ridges with width $2.5 \mathrm{~m}$ comparing to planting one ridge with width $1.25 \mathrm{~m}$. The values $56.50,49.00$ and $43.28 \mathrm{~cm}$.we found by planting one ridge width $.125 \mathrm{~m}$. Mean while the value decreased under planting two ridges with width $2.5 \mathrm{~m}$ were $49.00,44.00$ and $41.46 \mathrm{~cm}$. under traditional, siphon and gated pipes.

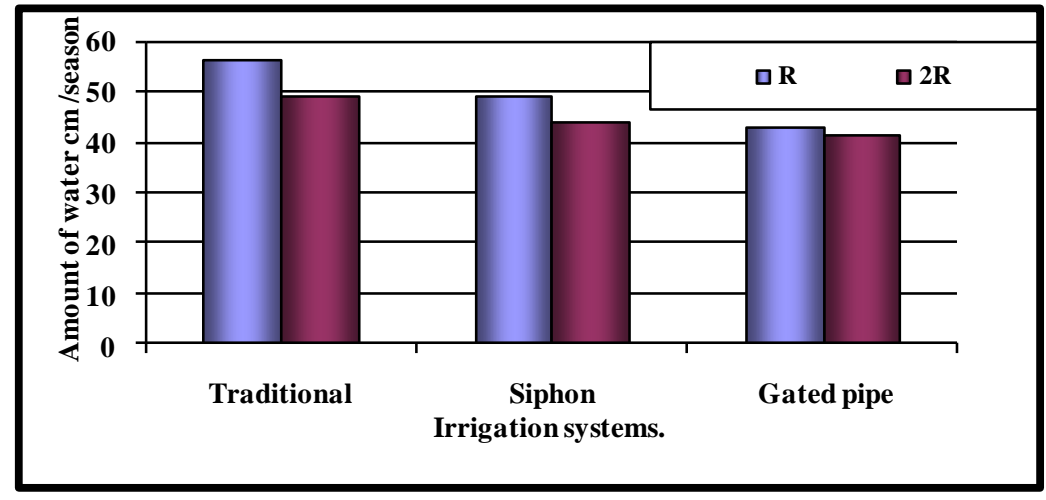

Fig. (2) : Effect of planting methods on amount of water irrigation under irrigation systems . 
Data in table (1) shown the effect of furrow width (width $1.25 \mathrm{~m}$ planting on one ridge and width $2.5 \mathrm{~m}$ with planting on two ridges) on irrigation water. Data indicate irrigation water decreased by $9.48 \%$ by planting two ridges with width $2.5 \mathrm{~m}$ compared to planting one ridge with width 1.25 $\mathrm{m}$. saving irrigated area water.

\section{2- Some plant characteristics}

\section{2-1Vegetative growth parameters.}

\section{2-1-1 Effect of irrigation systems .}

Data recorded in table (2) explain the effect of irrigation systems on growth parameter of Gurma watermelon plants expressed as plant fresh weight, stem length and number of branches /plant . Data indicated increasing plant fresh weight, stem length and number of branches /plant by $3.51,9.36,4.85,7.25,12.44$ and $22.91 \%$ respectively by using siphon and gated pipes compared to traditional irrigation.This increase is due to depth of the plant root in the soil profile under these systems compared to traditional irrigation system. .

\section{2-1-2 Depletion of available water.}

Data in table (2 ) reveal the reduced plant fresh weight, stem length and number of branches /plant by 3.78, $7.03,4.76,9.54,10.81$ and 14.62 \%by irrigation at depletions 60 and $80 \%$ of available water compared to irrigation at depletion of available water $40 \%$. This result is due to decreased soil moisture in the root zone.

Table (2) :Effect of irrigation systems and depletion of available water on vegetative growth parameters.

\begin{tabular}{|l|c|c|c|c|}
\hline $\begin{array}{l}\text { Irrigation } \\
\text { systems }\end{array}$ & $\begin{array}{c}\text { Depletions } \\
\text { of available } \\
\text { water }\end{array}$ & $\begin{array}{c}\text { Plant fresh } \\
\text { mass } \mathbf{( g )}\end{array}$ & $\begin{array}{c}\text { Stem } \\
\text { length } \\
\text { (cm) }\end{array}$ & $\begin{array}{c}\text { No. branches } \\
\text { /plant }\end{array}$ \\
\hline Traditional & $\mathbf{I}_{\mathbf{1}}$ & 590 & 202.5 & 3.3 \\
\hline & $\mathbf{I}_{\mathbf{2}}$ & 570 & 192.5 & 2.95 \\
\hline & $\mathbf{I}_{\mathbf{3}}$ & 550 & 182.5 & 2.8 \\
\hline Average & & 570 & 192.5 & 3.01 \\
\hline Siphon & $\mathbf{I}_{\mathbf{1}}$ & 610 & 206 & 3.4 \\
\hline & $\mathbf{I}_{\mathbf{2}}$ & 590 & 196 & 3.00 \\
\hline & $\mathbf{I}_{\mathbf{3}}$ & 570 & 186 & 2.9 \\
\hline Average & & 590 & 196 & 3.1 \\
\hline Gated pipe & $\mathbf{I}_{\mathbf{1}}$ & 650 & 219.5 & 3.55 \\
\hline & $\mathbf{I}_{\mathbf{2}}$ & 620 & 209.5 & 3.20 \\
\hline & $\mathbf{I}_{\mathbf{3}}$ & 600 & 199.5 & 3,05 \\
\hline Average & & 623.33 & 209.5 & 3.30 \\
\hline
\end{tabular}




\section{2-1-3 Effect of planting methods.}

Data in table ( 3 )reveal increase of plant fresh weight, stem length and number of branches /plant by planting two ridges with width $2.5 \mathrm{~m}$ compared to planting one ridge width $1.25 \mathrm{~m}$ by $2.65,3.77$ and $6.93 \%$ respectively. This result is due to efficiency of moisture distribution by planting two ridges with width $2.5 \mathrm{~m}$

Table ( 3 ) : Effect of planting on vegetative growth parameters.

\begin{tabular}{|l|c|c|c|c|}
\hline $\begin{array}{c}\text { Irrigation } \\
\text { systems }\end{array}$ & $\begin{array}{c}\text { Planting } \\
\text { methods. }\end{array}$ & $\begin{array}{c}\text { Plant fresh } \\
\text { mass }(\mathbf{g})\end{array}$ & $\begin{array}{c}\text { Stem } \\
\text { length }(\mathbf{c m})\end{array}$ & $\begin{array}{c}\text { No. of } \\
\text { branches } \\
\text { /plant }\end{array}$ \\
\hline Traditional & $\mathbf{R}$ & 565 & 190.0 & 2.90 \\
\hline & $\mathbf{2 R}$ & 575 & 195.0 & 3.12 \\
\hline Average & $\mathbf{R}$ & 570 & 192.5 & 3.01 \\
\hline Siphon & $\mathbf{2 R}$ & 592 & 192 & 3.00 \\
\hline & $\mathbf{R}$ & 590 & 198 & 3.20 \\
\hline Average & $\mathbf{2 R}$ & 633.66 & 215 & 3.10 \\
\hline Gated pipe & & 623.33 & 209.5 & 3.20 \\
\hline & & & & 3.30 \\
\hline Average & & &
\end{tabular}

2-2 Fruit characters.

\section{2-2-1 Effect irrigation systems .}

Data in table ( 4 ) indicate increase in fruit characters, i. e. fruit weight, length ,diameter. by $2.58,6.89,5.23,11.09,15$ and 21.7 by using siphon and gated pipes compared to traditional irrigation. This result may be due to growth of root and shoot system is better so plants which produced a high average of fruit weight, length and diameter. Data in table (4) illustrate that the result of ratio of homogeneous (length /diameter) increased by 7.21 and $9 \%$ by using siphon and gated pipe compared to traditional irrigation. This result means increasing fruit homogeneous shape by using siphon, gated pipes .The ratio length /diameter was about 1 i.e. the highest fruit homogeneous shape by using gated pipe .

\section{2-2-2 Depletion of available water.}

Also data in table (4) illustrate decreased fruit characters, i. e. fruit weight, length and diameter by $2.43,5.89,4.18,8.19,5.20$ and $10.93 \%$ under depletion of water available water $60 \%\left(\mathrm{I}_{2}\right)$ and depletion 
of available water $80 \%\left(\mathrm{I}_{3}\right)$ respectively compared to depletion of available water $40 \%$. This is due to decreased vegetative growth parameters. Fruit shape homogeneity is illustrated in table ( 4 ). Found that homogenous decrease ( i.e increased ratio length / width ) by depletion of available water increase from $40-80 \%$.The lowest value (1.04) was under depletion of available $40 \%\left(\mathrm{I}_{3}\right)$ and the highest value (1.06) was under depletion of available water $80 \%$ i.e by increasing depletion homogenuity decreased .Under depletion of available water 40 $\% \mathrm{I}_{3}$, fruit shape homogeneity increase due to similar length and width

Table (4) : Effect of irrigation systems and depletion of available water on fruit characters and homogeneity

\begin{tabular}{|l|c|c|c|c|c|}
\hline $\begin{array}{c}\text {.Irrigation } \\
\text { system }\end{array}$ & $\begin{array}{c}\text { Depletion } \\
\text { of } \\
\text { available } \\
\text { water }\end{array}$ & $\begin{array}{c}\text { Fruit } \\
\text { mass } \\
\mathbf{( g )}\end{array}$ & $\begin{array}{c}\text { Fruit } \\
\text { length } \\
\mathbf{( c m )}\end{array}$ & $\begin{array}{c}\text { Fruit } \\
\text { diamete } \\
\mathbf{r} \\
\text { (cm) }\end{array}$ & $\begin{array}{c}\text { Homogenuity } \\
\text { (length } \\
\text { /diameter) }\end{array}$ \\
\hline Traditional & $\mathbf{I}_{\mathbf{1}}$ & 601 & 11.39 & 10.30 & 1.10 \\
\hline & $\mathbf{I}_{\mathbf{2}}$ & 590 & 11,00 & 10.00 & 1.11 \\
\hline & $\mathbf{I}_{\mathbf{3}}$ & 570 & 10.27 & 9.10 & 1.13 \\
\hline Average & & 580.33 & 10.89 & 9.8 & 1.11 \\
\hline Siphon & $\mathbf{I}_{\mathbf{1}}$ & 606 & 12.0 & 11.8 & 1.02 \\
\hline & $\mathbf{I}_{\mathbf{2}}$ & 595 & 11.37 & 11.00 & 1.03 \\
\hline & $\mathbf{I}_{\mathbf{3}}$ & 585 & 10.90 & 10.46 & 1.04 \\
\hline Average & & 595.33 & 11.46 & 11.27 & 1.03 \\
\hline Gated pipe & $\mathbf{I}_{\mathbf{1}}$ & 631 & 12.50 & 12.50 & 1.00 \\
\hline & $\mathbf{I}_{\mathbf{2}}$ & 620 & 12.00 & 11.80 & 1.01 \\
\hline & $\mathbf{I}_{\mathbf{3}}$ & 610 & 11.77 & 11.50 & 1.02 \\
\hline Average & & 620.33 & 12.09 & 11.93 & 1.01 \\
\hline
\end{tabular}

\section{2-2-3 Effect planting methods}

Data in table ( 5 ) indicate increase in fruit characters, i. e. fruit weight, length , diameter. by $2.37,6.26$ and $13.92 \%$ respectively by planting two ridges with width $2.5 \mathrm{~m}$ compared to planting one ridge with width 1.25 $\mathrm{m}$.This data is due to moisture distribution and vegetative growth under planting two ridges with width $2.5 \mathrm{~m}$.

Fruit shape homogeneity is affected by planting method data in table 
( 5 ) .We found ,increase by $7.34 \%$ under planting two ridges with width $2.5 \mathrm{~m}$ compared to planting one ridge with width $1.25 \mathrm{~m}$ i. e. increase fruit shape homogenuity due to similar length with diameter.

Table (5): Effect of planting methods on fruit characters and homogeneity

\begin{tabular}{|l|c|c|c|c|c|}
\hline $\begin{array}{c}\text { Irrigation } \\
\text { system }\end{array}$ & $\begin{array}{c}\text { Planting } \\
\text { methods } \\
\text {. }\end{array}$ & $\begin{array}{c}\text { Fruit } \\
\text { mass } \\
\text { (g) }\end{array}$ & $\begin{array}{c}\text { Fruit } \\
\text { length } \\
\text { (cm) }\end{array}$ & $\begin{array}{c}\text { Fruit } \\
\text { diameter } \\
\text { (cm) }\end{array}$ & $\begin{array}{c}\text { Homogenuity } \\
\text { (length/ } \\
\text { diameter) }\end{array}$ \\
\hline Traditional & $\mathbf{R}$ & 575 & 10.60 & 8.83 & 1.2 \\
\hline & $\mathbf{2 R}$ & 585.6 & 11.18 & 10.85 & 1.03 \\
\hline Average & & 580.3 & 10.89 & 8.84 & 1.11 \\
\hline Siphon & $\mathbf{R}$ & 590 & 11.30 & 10.76 & 1.05 \\
\hline & $\mathbf{2 R}$ & 600.6 & 11.62 & 11.50 & 1.01 \\
\hline Average & & 595.3 & 11.46 & 11.13 & 1.03 \\
\hline Gated pipe & $\mathbf{R}$ & 610.6 & 11.50 & 11.17 & 1.03 \\
\hline & $\mathbf{2 R}$ & 630. & 12.68 & 12.68 & 1.00 \\
\hline Average & $\cdot$ & 620.3 & 12.09 & 6.34 & 1.01 \\
\hline $3-Y$
\end{tabular}

\section{3 - Yield}

\section{3-1 Effect of irrigation systems}

Data in table (6) indicate increased yield of Gurma watermelon by 4.85 and $7.25 \%$ by using siphon and gated pipes compared to traditional irrigation. This result is due to root and shoot system is better so increase of growth vegetative and fruit weight .

Table (6) Effect of irrigation systems, depletion of available water and planting methods on yield and water use irrigation

\begin{tabular}{|c|c|c|c|}
\hline $\begin{array}{c}\text {.Irrigation } \\
\text { system }\end{array}$ & $\begin{array}{c}\text { Applied water } \\
\text { Cm./season. }\end{array}$ & $\begin{array}{c}\text { Yield } \\
\text { kg /fed. }\end{array}$ & W U E \\
\hline Traditional & 51.97 & 556.33 & 10.63 \\
\hline Siphon & 45.82 & 583.33 & 12.55 \\
\hline Gated pipe & 42.46 & 596.67 & 14.07 \\
\hline $\mathbf{I}_{\mathbf{1}}$ & 50.20 & 604.08 & 12.03 \\
\hline $\mathbf{I}_{\mathbf{2}}$ & 46.33 & 570,74 & 12.32 \\
\hline $\mathbf{I}_{\mathbf{3}}$ & 44.00 & 561.52 & 12.76 \\
\hline $\mathrm{R}$ & 46.27 & 566.67 & 11.42 \\
\hline $2 \mathrm{R}$ & 44.00 & 590.88 & 13.18 \\
\hline
\end{tabular}




\section{3-2 Depletion of available water.}

Yield of Gurma watermelon in Fig. ( 3)show different ratios of depletion of available water, under all irrigation systems . By increasing depletion yield decreased .Under depletion $40 \%$ of available water the highest value of yield was $630 \mathrm{~kg} / \mathrm{fed}$. under gated pipes, followed by $610 \mathrm{~kg} / \mathrm{fed}$. by using siphon and the lowest value of $583 \mathrm{~kg} / \mathrm{fed}$, under traditional irrigation.

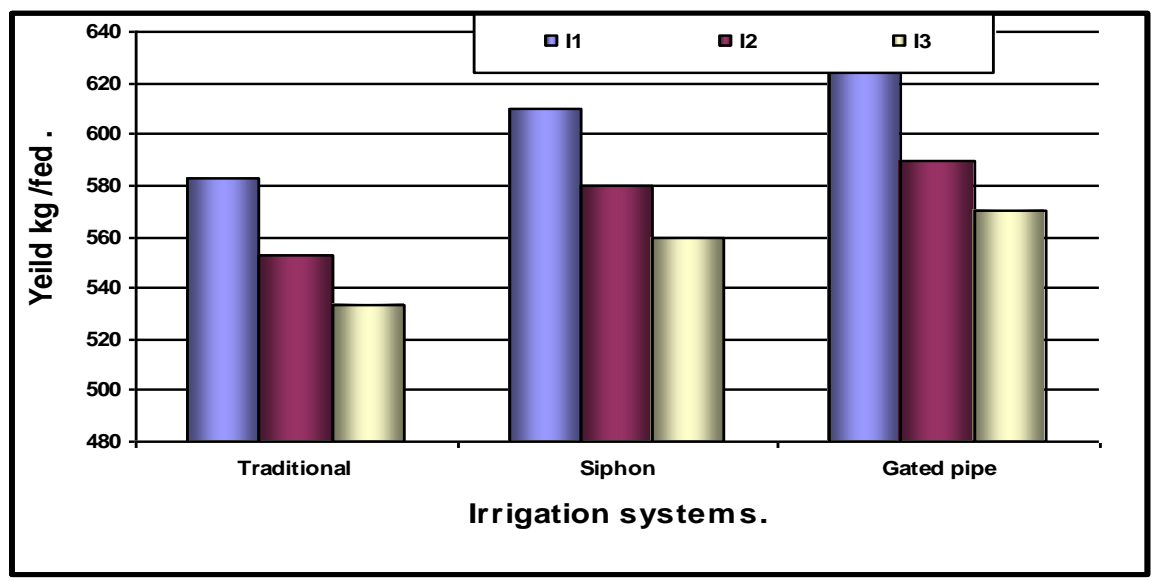

Fig. ( 3): Effect of available water depletion under irrigation systems on yield .

Data in table ( 6 ) indicate that yield of Gurma watermelon decrease by 5.52 and $7.05 \%$ with irrigation when moisture depletion was 60 and 80 $\%$ compared to irrigated when moisture depletion was $40 \%$. This result is due to decreased fruit weight.

\section{3 -3 Effect of planting methods.}

Values of Gurma watermelon yield was affected by planting methods under irrigation systems as shown in fig. (4). Yield increased by planting two ridges with width $2.5 \mathrm{~m}$ under irrigation systems comparing to planting one ridge width $1.25 \mathrm{~m}$. Highest value was $603.32 \mathrm{~kg} / \mathrm{fed}$, by planting two ridges under gated pipes, followed by $596.66 \mathrm{~kg} / \mathrm{fed}$., where the lowest value was $572.66 \mathrm{~kg} / \mathrm{fed}$. Under gated pipes, siphon and traditional irrigation systems respectively . 


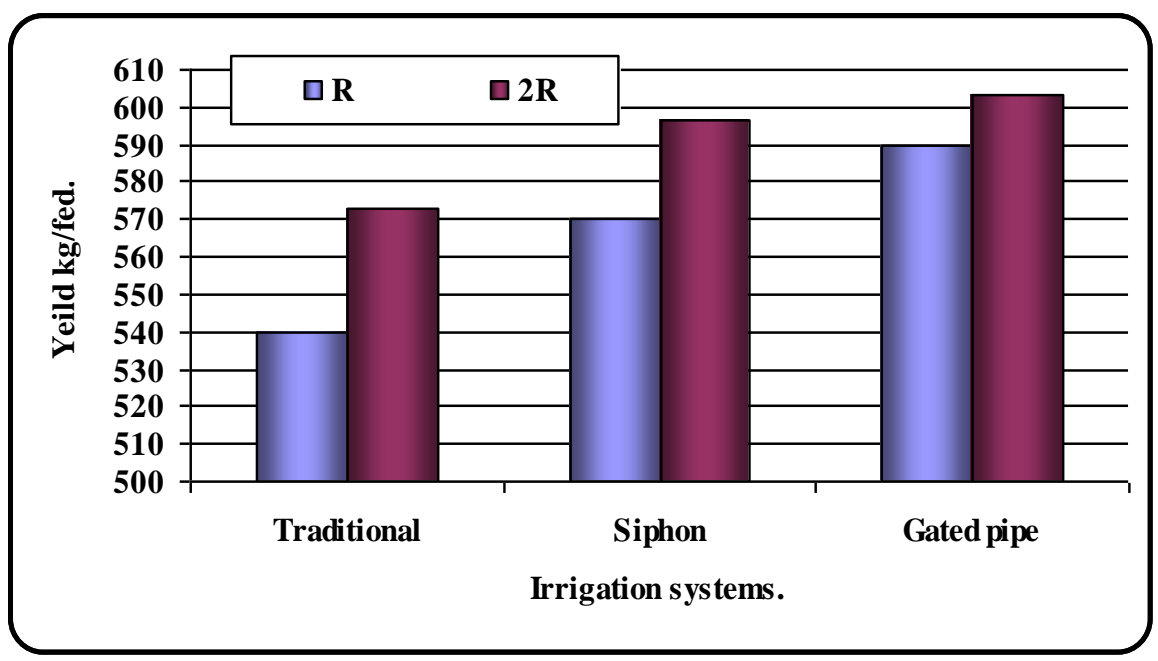

Fig. (4) : Effect of planting methods under irrigation systems on yield

Data in table (6) show yield of watermelon increased by $4.27 \%$ with planting two ridge with width $2.5 \mathrm{~m}$.This is due to the vegetative growth and fruit weight increases .

\section{4 - Water use efficiency ( W U E)}

\section{4 -1 Effect of irrigation systems}

Data in table (6) show effect of irrigation systems on water use efficiency . Found that increase in (W U E ) by 18.06 and $32.36 \%$ under siphon and gated pipes compared to traditional irrigation. This result is due to increased yield and decrease irrigation water by using siphon and gated pipes irrigations .

\section{4-2 Depletion of available water.}

The water use efficiency has been used to evaluate different depletion ratios data in fig. (5). Values of water use efficiency increase by decreasing depletion ratio under irrigation systems .The highest values were $10.84,12.73$ and $14.25 \mathrm{~kg} /$ fed.cm. by depletion $80 \%$ under traditional, siphon and gated pipes respectively . 


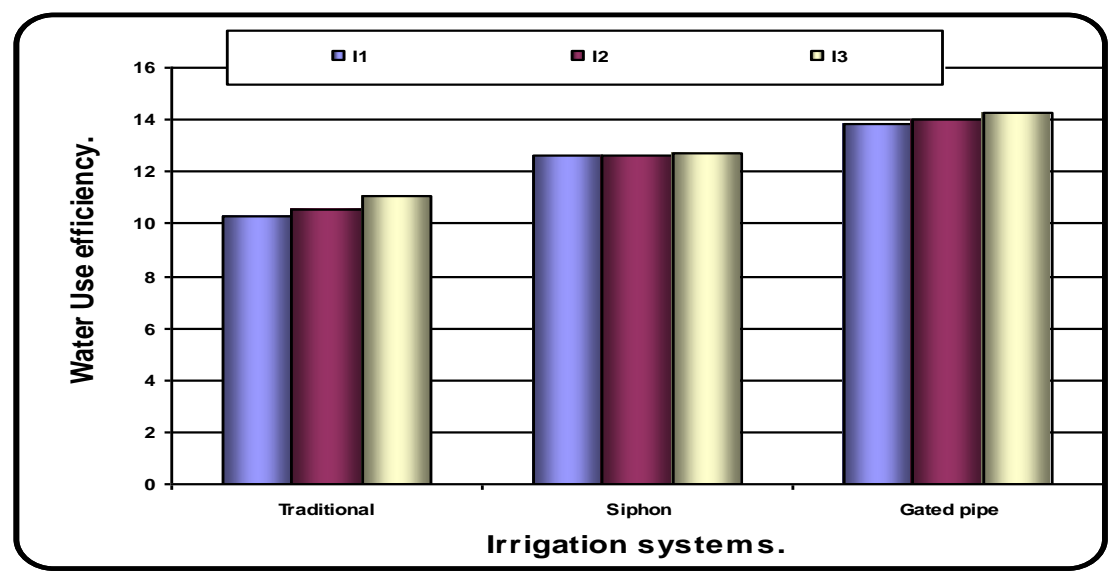

Fig. ( 5) : Effect of depletion of available water under irrigation systems on water use efficiency .

Also data in table (6) show the effect of soil moisture depletion on water use efficiency (W U E). Found that increase in water use efficiency by 2.41 and $6.08 \%$ under irrigation at soil moisture depletions $60\left(\mathrm{I}_{2}\right)$ and $80 \%\left(\mathrm{I}_{3}\right)$ compared by irrigation at soil moisture depletion $40 \%$. This result is due to decreased amount of irrigation water under $\mathrm{I}_{2}$ and $\mathrm{I}_{3}$

\section{4-3 Effect of planting methods}

Water use efficiency is shown in fig. (6). The value under planting two ridges with width $2.5 \mathrm{~m}$ give the highest value 14.55 followed by 13.56 while the lowest was $11.69 \mathrm{~kg} / \mathrm{fed}$. cm. for gated pipes ,siphon and traditional .

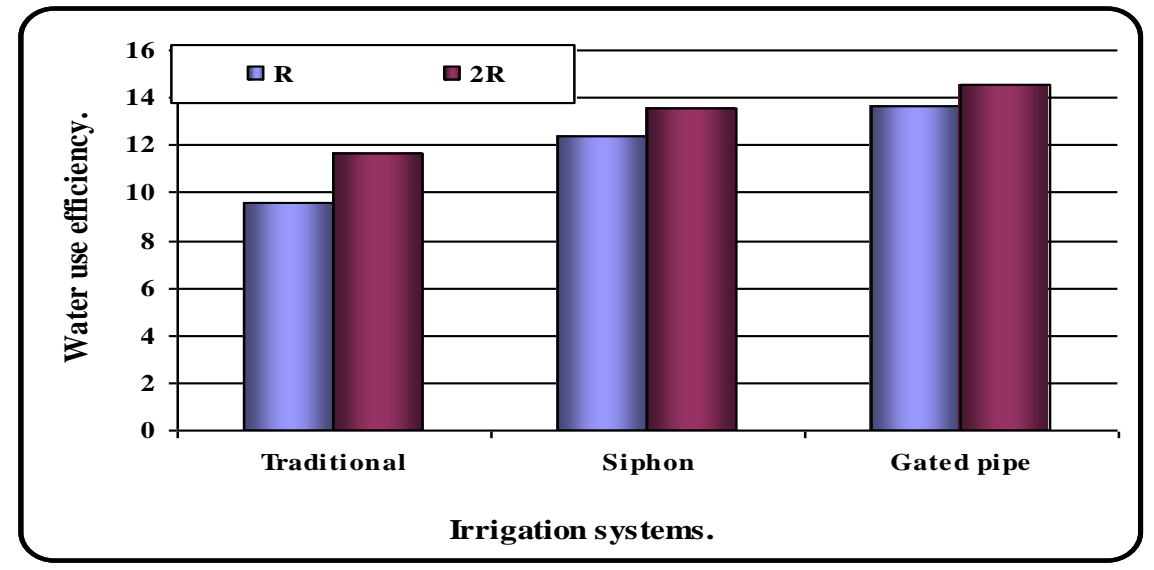

Fig. ( 6) : Effect of planting methods under irrigation systems on water use efficiency . 
Data in table (6) show the effect of planting methods on water use efficiency. Data indicated increased water use efficiency by $15.41 \%$ under planting two ridges with width $2.5 \mathrm{~m}$ compared to planting one ridge with width $1.25 \mathrm{~m}$.This is due to increased yield and decreased amount of irrigation water under planting two ridges with width of $2.5 \mathrm{~m}$

\section{CONCLUSIONS}

The main results in the present work can be summarized in the following points:

1- Increased vegetative and fruit characters, fruit shapehomogenuity , yield and water use efficiency resulted by using gated pipes compared to other irrigation systems and planting two ridges compared to planting one ridge .

2- Irrigation water is saved by using gated pipes compared to other irrigation systems and planting two ridges with width $2.5 \mathrm{~m}$ compared to planting one ridge.

3- Yield and its components decreased when irrigating at soil moisture depletion 60 and $80 \%$ compared to irrigation at soil moisture depletion of $40 \%$.

\section{REFERENCES}

Abdel- Aziz ,A. A. ( 2003 ) .Possibility of applying modern irrigation systems in the citrus farms and economic return. J.Agric. Sci. Mansoura Univ. , 28(7) : 5621- 5635, 2003.

\section{Abo soliman ,M. S. M., H. E. Osman, M.M.Said and E.H.Osman} (2005). Maiza, berly production and water use efficiency as influenced by different irrigation methods in Egyption old land . $13^{\text {th }}$ Ann.Conf. of Misr Soc. Agric. Eng. ,14-15 Dec. 1-22.

Attai, M.M.;A.M. Osman, M. A. Sayed and A.A.El-Kafory (1999).Effect of irrigation intervals and row width on-yield, water use efficiency and some economic studies on sesame in calcareous soil .Soil Water and Eviron Res.Inst. $3^{\text {rd }}$ Conf.On- Farm Irrigation and Agroclimatology, January 25-27, 1999, Giza. 
James,L.C.(1988). Principles of farm irrigation system design . N. Y. , Wiley and sons, $410 \mathrm{p}$

Israelsen, O.W. and Hansen, V.E. (1962). Irrigation Principles and Practice $3^{\text {rd }}$ Ed. John Willey and Sons. Inc., New York

Michael ,A. M. (1978). Irrigation theory and practice. Viskas Pub. House PVTLTD: New Delhi. Luck, A.N. Merrian, J83.

Hayam ,S. Mahgoub and M. A. Sayed (2001 ). Response of two wheat cultivars to irrigation amount and nitrogen level in sandy soil .Mansoura Univ. J.of Agric. Sci., 26(4) : 1863- 1873 .

Hefnawy ., F.A. and M. F. Wahba (2003) .Effect of water stress in late growth stages of some wheat cultivars . J. Agric. Mansoura Univ. , 28 (2) 792-745, 2003.

Hefni, E. H. ; El-Hosary, A. A. ; Salwau, M. I. M. and El-Sabbagh, a. (1993).Effect of soil moisture stress and foliar application of zinc on Maize varieties III soil water relations .Annals of Agric. Sc. Moshtohor. Vol. 31(4) , 1993.

Humphrays ,A. S. (1986) Automaled farm surface irrigation system world wide .Special publ. ,ICID,New Delhi ,MI,:829.

Omara , A. ( 1997) Implementation and evaluation of gated pipe for furrow irrigation system M. Sc. Agric. Eng. Dept. Alex.

Osman,H.E. ,H. S. Mehawed and A.A.Abdel-Aziz (2005). Using modified surface irrigation in old land mango farm in Nile Valley, watershed management to meet water quality standerds and emerging, TMDL (total maximum daily load) $3^{\text {rd }}$ Conf. March, 5$9^{\text {th }}$, 20701P0705,ASAE,Atlanta ,Georgia, USA.

Shalaby, E. E.;M. M.El-Ganbeehy and M. H. El-Sheikh(1992) .Performance of wheat genotypes under drought stress . Alex. J. Agric. Res., 37 (1) :33-51 .

Yousef ,K.M. R. and R. A. Eid (1994). Soil moisture stress and nitrogen fertilization effect on wheat yield and water use . Egypt . J. Appl. Sci .9 (4) : 784-785 . 


\section{الملخص العربيى \\ رى بطيخ اللب فى الوادى القديم بالانابيب المبوبة والسيفون \\ أمال فتوح الثرقاوى"- محمد يسرى بندق*"}

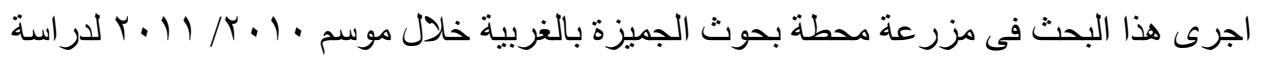

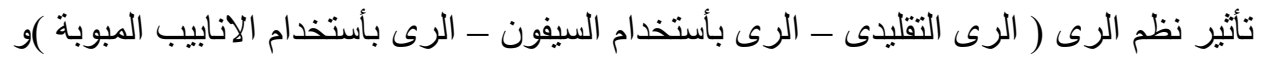

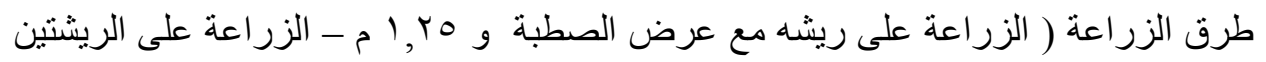

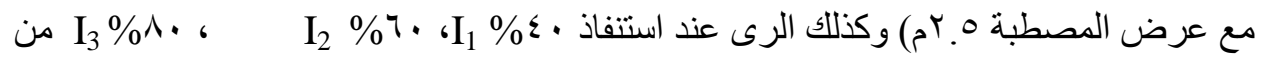
الماء الميسر بالتربة على المكونات الخضرية والمكونات الثمرية والاتنتاجية وكفاءة استخدام

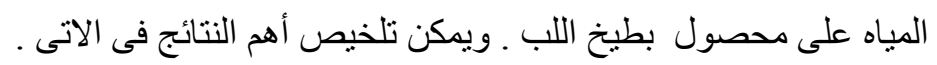

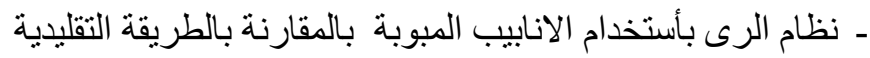

ـ ـ أدى زيادة جودة الصفات الخضرية لمحصول بطيخ اللب مثل وزن النبات وطول الساق و

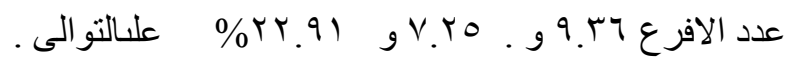

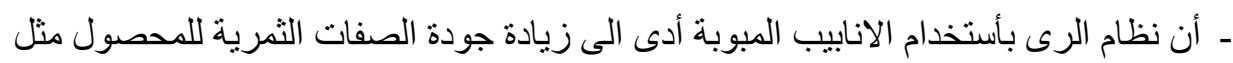

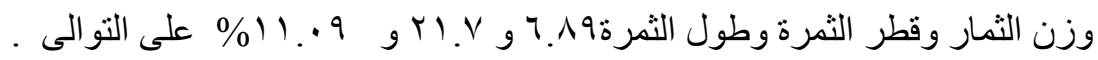

ـ أن نظام الرى بأستخدام الانابيب المبوبة أدى الى زيادة التجانس والتماثل بين الثمار بنسة $\% 9$

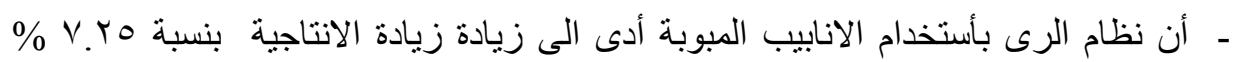

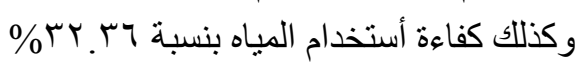

ـ أدى نظام الزر اعة على ريشتين مع عرض المصطبة ه. بم الى تقليل مياه الرى بالمفارنة

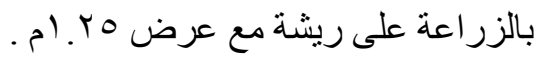
ـ أدى نظام الزراعة على ريشتين مع عرض المصطبة ه.بم الى زيادة الخصائص الخضرية

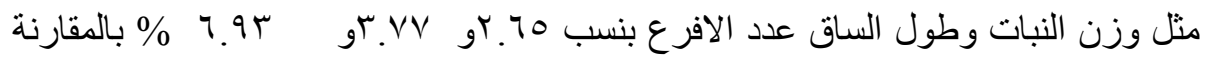

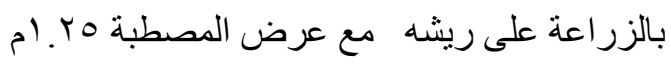

* باحث أول معهد بحوث الهندسة الزراعية الدقي

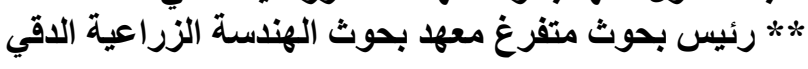


ـ أدى نظام الزراعة على ريشتين مع عرض المصطبة ه.rم الى زيادة الخصائص الثمرية

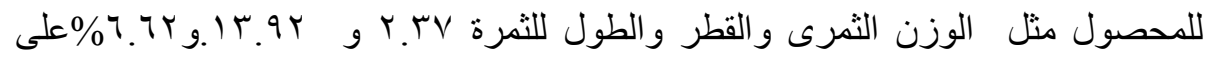
التو الى

ـ أدى نظام الزراعة على ريشتين مع عرض المصطبةه.r ام الى زيادة التجانس للثمار (نسبة

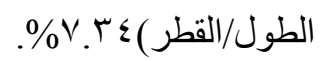

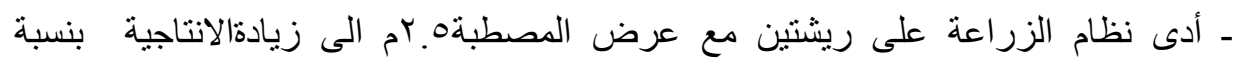

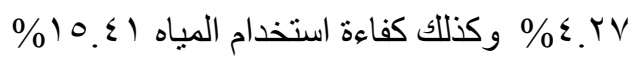
ـ أدى تعرض النبات للاجهاد الطوبى .

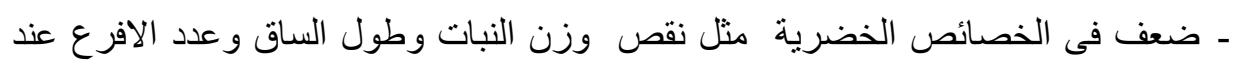

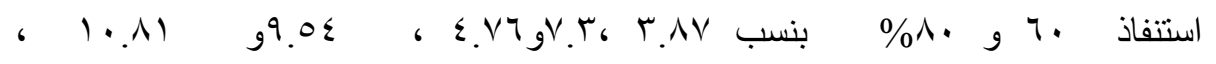

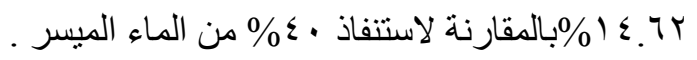

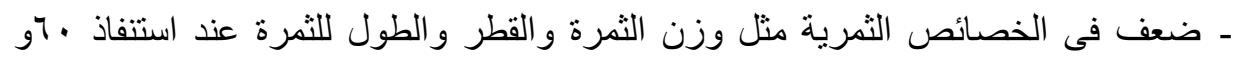

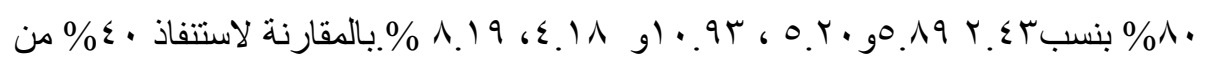
الماء الميسر.

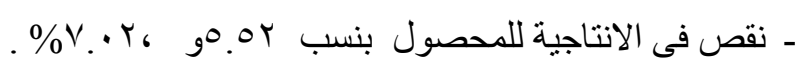

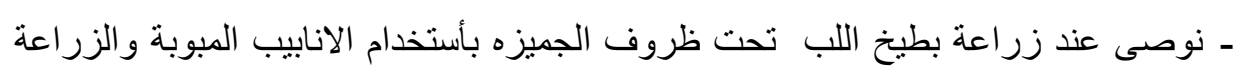

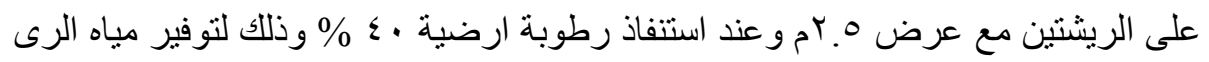
ولزيادة الانتاجية وللحصول على اعلى كفاءة استخدام للمياه . 